\title{
PREVALENCE OF AMBLER CLASS A EXTENDED-SPECTRUM- $\beta$ - LACTAMASES (ESBLS) AMONG UROPATHOGENIC Escherichia coli STRAINS ISOLATED FROM RASHT CITY, IRAN
}

\author{
PREVALENNCIA DE AMBLER EXTENDED-SPECTRUM CLASSE A- $\beta$-LACTAMASES \\ (ESBLS) ENTRE UROPATHOGENIC Escherichia coli ISOLADOS DA CIDADE DE \\ RASHT, IR $\tilde{A}$
}

\author{
Hojjatolah ZAMANI ${ }^{1}$; Ali SALEHZADEH ${ }^{2, *}$; Seddigheh ZARRIN ${ }^{2}$ \\ 1. Department of Biology, Faculty of Science, University of Guilan, Rasht, Iran 2. Department of Biology, Rasht Branch, Islamic \\ Azad University, Rasht, Iran.*Corresponding Author: salehzadeh@iaurasht.ac.ir
}

\begin{abstract}
Extended spectrum $\beta$-lactamases (ESBLs), a group of bacterial enzymes which are the major cause of resistance to penicillins, broad spectrum cephalosporins and monobactams, are found among the member of Enterobacteriaceae. The class A ESBLs are mainly encoded by the plasmid mediated $b a_{S H V}, b_{1} a_{T E M}$ and bla $_{C T X-M}$ genes. In this study, prevalence of Ambler class A ESBL genes among uropathogenic E. coli (UPEC) isolates associated with community acquired infections and their antibiotic susceptibility pattern was investigated. Seventy UPEC strains were isolated from urine samples and subjected to antimicrobial susceptibility assay using disk diffusion method. Phenotypic screening of ESBL production was evaluated according to the CLSI combined disk method. Genotyping of Ambler class A ESBLs was investigated using PCR. According to the results, ESBLs was identified in 37 isolates while molecular assay showed 47 isolates harbored ESBL genes. The most prevalence was recorded for $b l a_{T E M}(74.2 \%)$ followed by $b_{1} a_{C T X-M}$ $(43.2 \%)$ and $b a_{S H V}(12.2 \%)$. Imipenem was the most effective drug and ESBL producing isolates showed higher resistance to CAZ, CRO, CFZ, CTX and FOX compared to non ESBL isolates. In conclusion, high prevalence of class A ESBL genes was observed in our study which needs more consideration and rational antibiotic prescription.
\end{abstract}

KEYWORDS: Antibiogram. ESBL. Phenotypic combined disk. Uropathogenic E. coli.

\section{INTRODUCTION}

$\beta$-Lactamases are bacterial enzymes that inactivate $\beta$-lactam antibiotics by hydrolysis of $\beta$ lactam ring, which result in ineffective compounds. At least 400 different types of b-lactamases, originating from clinical isolates, have been described (PARVEEN et al. 2012). ExtendedSpectrum- $\beta$-Lactamases (ESBLs) are regarded as the major cause of resistance to penicillins, broad spectrum cephalosporins and monobactams among Enterobacteriaceae. These enzymes are found predominantly in Escherichia coli (E. coli) and Klebsiella species and have been described in other Enterobacteriaceae as well (GARZA-GONZÁLEZ et al. 2011).

The Ambler class A ESBLs are mainly encoded by the bla $_{S H V}, b l a_{T E M}$ and $b l a_{C T X-M}$ genes which are generally found in plasmids and readily spread among different members of the Enterobacteriaceae. Currently, hundreds variants of ESBLs have been reported worldwide which arise mainly due to point mutations in ESBLs encoding genes (GARZA-GONZÁLEZ et al. 2011; KAUR; AGGARWAL 2013). Although $S H V$ and TEM variants are the most frequent ESBLs, the $C T X-M$ family of ESBLs have became prevalent in many regions. The $C T X-M$ family of enzymes appears to have arisen by initial transfer of the chromosomal $\beta$ lactamase gene from Kluyvera species to conjugative plasmids that have readily spread among different members of the Enterobacteriaceae and certain other gram-negative bacteria (JORGENSEN et al. 2010).

Uropathogenic Escherichia coli (UPEC) strains are important causal agent of Urinary Tract Infections (UTIs). ESBL producing bacteria show resistance to penicillins, extended spectrum cephalosporins and monobactams, resulting in failure of antibiotic therapy. Plasmids responsible for ESBL production frequently carry genes encoding resistance to other drug classes (e.g. aminoglycosides, tetracycline, chloramphenicol). Therefore, antibiotic options in the treatment of ESBL-producing organisms are extremely limited (CANTON et al. 2008). Thus, detection of the common ESBL genes such as bla $a_{T E M}$, bla $a_{S H V}$ and $b l a_{C T X-M}$ by molecular methods in the ESBL producing bacteria and their patterns of antimicrobial resistance can provide valuable information about their epidemiology and can aid a rational antimicrobial therapy.

The present study was conducted to evaluate the prevalence of ESBL producing 
Prevalence of ambler class...

uropathogenic E. coli and to detect the presence of bla $a_{T E M}, b l a_{S H V}$ and $b l a_{C T X-M}$ genes among ESBL producing isolates. In addition, antibiotic resistance profile of the isolates was investigated.

\section{MATERIAL AND METHODS}

\section{Clinical isolates}

In this study 70 urinary E. coli isolates were collected from patients with community acquired infections referring to clinical laboratory of Rasht city (Iran) during the period of February 2015 to January 2016. Clinical isolates were obtained from patients within an age range of 17 and 66 years (mean age $=37.9$ years). Fifty-three strains were isolated from females (with a mean age of 35.4 years), and the remaining were obtained from males (with a mean age of 46.4 years). Bacterial identification was performed by conventional biochemical methods and all isolates were stored at $-70^{\circ} \mathrm{C}$ in Tryptic Soy broth containing $20 \%$ glycerol for subsequent analysis.

\section{Antimicrobial susceptibility testing}

The isolates were tested for their antimicrobial susceptibilities by the Kirby-Bauer disc diffusion technique according to the Clinical and Laboratory Standards Institute (CLSI) guideline using the following antibiotics(CLSI 2012): Ceftazidime $(30 \mu \mathrm{g})$, Cefazoline $(30 \mu \mathrm{g})$, Imipenem $(10 \mu \mathrm{g})$, Ceftriaxone $(30 \mu \mathrm{g})$, Cefotaxime $(30 \mu \mathrm{g})$, Piperacillin $(100 \mu \mathrm{g})$, Nalidixic acid $(30 \mu \mathrm{g})$, Ciprofloxacin $(5 \mu \mathrm{g})$, Cefoxitin $(30 \mu \mathrm{g})$. E. coli ATCC 25922 and E. coli ATCC 35218 were used as the reference strains to control the quality of the applied antimicrobial agents (CLSI 2012).

\section{Phenotypic detection of ESBLs}

The ESBL phenotypic detection test was performed using the combination disc method on all
ZAMANI, H.; SALEHZADEH, A.; ZARRIN, S.

isolates. Briefly, a disc of ceftazidime $(30 \mu \mathrm{g})$ alone and ceftazidime + clavulanic acid $(30 \mu \mathrm{g} / 10 \mu \mathrm{g})$ were placed at a distance of $25 \mathrm{~mm}$, center to center, on a Muller Hinton Agar (MHA) plate inoculated with a bacterial suspension of 0.5 McFarland turbidity standards and incubated overnight at $37^{\circ} \mathrm{C}$. An increase in the inhibition zone diameter of $5 \mathrm{~mm}$ for a combination disc versus ceftazidime disc alone confirmed ESBL production (CLSI 2012). According to the CLSI guideline, cefotaxim could also be used instead of ceftazidime in the phenotypic detection assay (CLSI 2012).

\section{Molecular identification of ESBL genes}

Polymerase Chain Reaction (PCR) was employed to detect bla $_{S H V}$, bla $_{T E M}$ and $b l a_{C T X-M}$ genes among all 70 UPEC isolates. Bacterial plasmid extraction was performed using Viogene ${ }^{\circledR}$ plasmid DNA extraction kit according to the manufacturer's protocol. Briefly, the isolates were grown in Luria broth (Merck, Germany) overnight at $37^{\circ} \mathrm{C}$, centrifuged at $8000 \mathrm{rpm}$ for 10 minutes. The supernatant was discarded and the pellet was resuspended in $200 \mu \mathrm{L}$ MX buffer. Then, $250 \mu \mathrm{L}$ of $\mathrm{MX}_{2}$ buffer was added and incubated for 1-2 minutes at room temperature in order to lyse bacterial cells. After that, $\mathrm{MX}_{3}$ buffer $(350 \mu \mathrm{L})$ was added to neutralize the lysates. The cell lysates were centrifuged at $10000 \times \mathrm{g}$ for $5 \mathrm{~min}$ and plasmid DNA precipitated by WN buffer and purified using spin columns.

The master mix for the PCR was prepared as follows: $3 \mu \mathrm{L}$ of $10 \times$ PCR buffer, $3 \mu \mathrm{L}$ of $25 \mathrm{mM}$ $\mathrm{MgCl}_{2}, 3 \mu \mathrm{Lof} 10 \mathrm{mM}$ dNTP mix, $0.5 \mu \mathrm{L}$ of Taq DNA Polymerase , $9.5 \mu \mathrm{L}$ of MilliQ water and $1 \mu \mathrm{L}$ of each of the forward and reverse primers. Finally, $4 \mu \mathrm{L}$ of each DNA template was added in the corresponding tubes to make up the final reaction volume of $25 \mu \mathrm{L}$. The PCR primer pairs used in this study were presented in Table 1.

Table1. Primer pairs used for amplification of Ambler class A ESBL genes

\begin{tabular}{llcc}
$\begin{array}{l}\text { Target } \\
\text { gene }\end{array}$ & \multicolumn{1}{c}{ Primers (5'-3') } & $\begin{array}{c}\text { Size of } \\
\text { PCR } \\
\text { product } \\
\text { (bp) }\end{array}$ & Reference \\
\hline${ }^{2} l a_{T E M}$ & $\begin{array}{l}\text { F: TCC GCT CAT GAG ACA ATA ATA ACG } \\
\text { R: TTG GTC TGA TGA CAG TTA CCA ATG }\end{array}$ & 930 & (Kiratisin et al. 2008) \\
\hline \multirow{2}{*}{$b l a_{S H V}$} & $\begin{array}{l}\text { F: TGG TTA TGC GTT ATA TTC GCC } \\
\text { R: GGT TAG CGT TGC CAC TGCT }\end{array}$ & 868 & (Park et al. 2006) \\
\hline \multirow{2}{*}{$b l a_{C T X-M}$} & $\begin{array}{l}\text { F: TCTTCCAGAAGGAATCCC } \\
\text { R: CCGTTTCCGCTATTACAAAC }\end{array}$ & 909 & (Kiratisin et al. 2007) \\
\hline
\end{tabular}


The reaction mix was incubated at $94^{\circ} \mathrm{C}$ for 5 min followed by 30 cycles of PCR, denaturation for $50 \mathrm{~s}$ at $94^{\circ} \mathrm{C}$, primer annealing at $53{ }^{\circ} \mathrm{C}$ for both bla $a_{S H V}$ and $b l a_{T E M}$ and $54^{\circ} \mathrm{C}$ for $b l a_{C T X-M}$ for $30 \mathrm{~s}$ and polymerization at $72{ }^{\circ} \mathrm{C}$ for $1 \mathrm{~min}$, was conducted. The polymerization was concluded by an extension period of $10 \mathrm{~min}$ at $72{ }^{\circ} \mathrm{C}$. Then, PCR products were mixed with $3 \mu \mathrm{L}$ Power load DNA stain and were visible after electrophoresis in a $1 \%$ agarose gel in TBE buffer and under UV transillumination.

\section{RESULTS}

\section{Clinical isolates}

A total number of 70 UPEC strains were isolated from UTIs. The majority of the isolates associated to women's UTI (63 isolates), whereas only 7 UPEC were isolated from men's urine samples.

\section{Antibiotic susceptibility profile \\ Among 70 UPEC isolates, 25 isolates (35.7\%) displayed resistance to at least three cephalosporines $\left(3^{\text {rd }}\right.$ and $4^{\text {th }}$ generations). None of isolates were piperacillin susceptible while imipenem was found to be the most efficient antibiotic with $88.6 \%$ susceptibility of the isolates. In addition the isolated strains indicated $50 \%$ and $64.28 \%$ resistance to ciprofloxacin and nalidixic acid, respectively. The antibiotic susceptibility patterns of the isolates were presented in Table 2.}

Table 2. antimicrobial drug resistance among the isolates.

\begin{tabular}{ccccccccccc}
\hline \multirow{2}{*}{$\begin{array}{c}\text { ESBL genes } \\
\text { Prevalence } \\
(\mathrm{n})\end{array}$} & \multicolumn{8}{c}{ Antibiotic Resistance (\%) } \\
\cline { 3 - 10 } & & CAZ* & CRO* & CFZ* $^{*}$ & CTX $^{*}$ & FOX* & NX & PIP & CIPX & IPM \\
\hline ESBL strains & 47 & 42.5 & 59.5 & $55.3 \%$ & 44.6 & 40.4 & 63.8 & 87.2 & 53.2 & 10.6 \\
$\quad \begin{array}{c}\text { Non ESBL } \\
\text { strains }\end{array}$ & 23 & 21.7 & 34.7 & $26.0 \%$ & 17.4 & 21.7 & 65.2 & 91.3 & 47.8 & 15.0 \\
\hline
\end{tabular}

CAZ, ceftazidime; CRO, ceftriaxone, CFZ, cefazolin; CTX, cefotaxime; FOX, cefoxitin NX, Nalidixic acid; PIP, piperacillin; CIPX, ciprofloxacin; IPM, imipenem; *Significant with $\mathrm{P}$ value less than 0.01 .

\section{Prevalence of ESBLs}

ESBLs production among UPEC isolates was evaluated using phenotypic confirmatory test (Fig 1). According to the results, ESBL was noted in 37 isolates (52.8\%). Prevalence of Ambler class A ESBL genes was investigated among all 70 isolates and the results were compared to the results from phenotypic test. Molecular detection of ESBL genes among UPEC isolates showed that $67.1 \%(n=47)$ of the isolates harbor at least one ESBL genes. Our results indicated that the $b a_{T E M}$ was the most prevalent ESBL gene (50\%) while the least frequency was observed for $b l a_{S H V}(8.5 \%)$. The molecular characterization revealed that $22.8 \%$ of isolates possessed the $b l a_{C T X-M}$ gene alone, while $35.7 \%$ and $8.5 \%$ of the isolates had $b l a_{T E M}$ and $b l a_{S H V}$ genes alone, respectively. The $b l a_{C T X-M}$ and $b l a_{T E M}$ genes together were found in $10 \%$ of isolates and $4.2 \%$

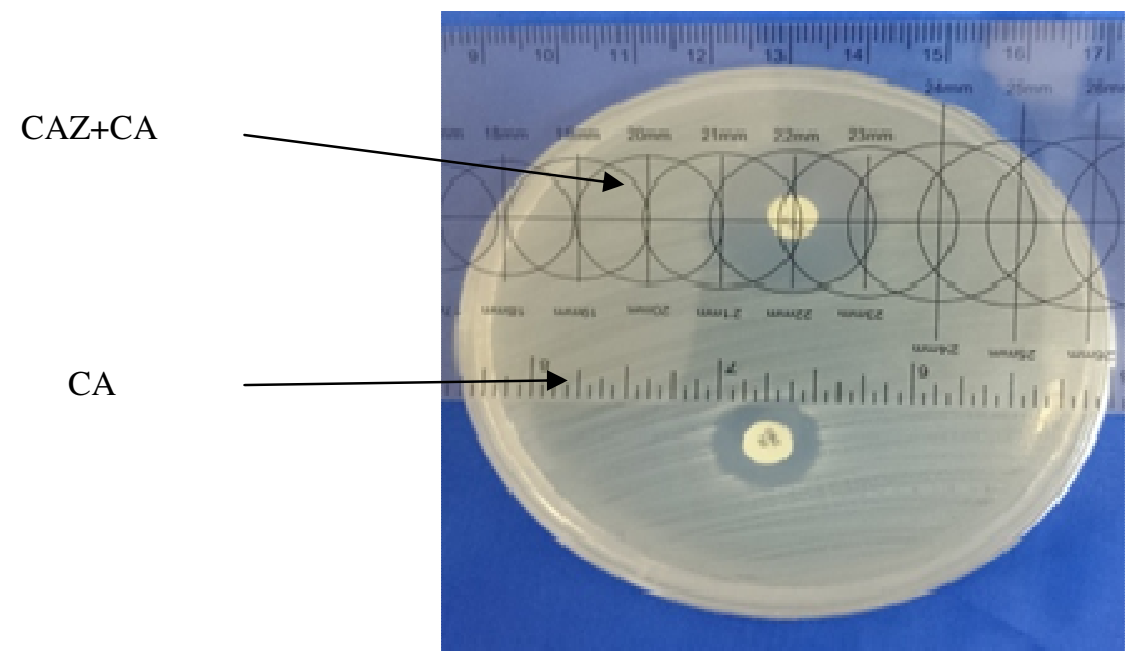

Figure 1. Screening of ESBLs producers by phenotypic combined disk assay. CAZ: ceftazidime; CA: clavulanic acid. 


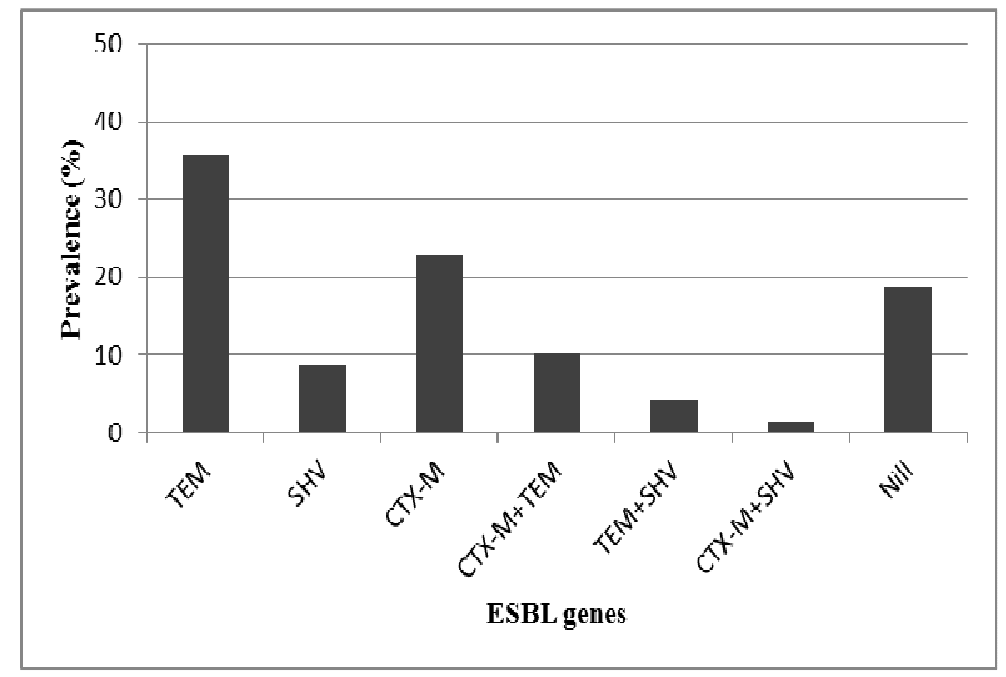

Figure 2. Prevalence of different ESBL genes among the isolates had $b l a_{T E M}$ and $b l a_{S H V}$ together. In addition, only one isolate harbored both $b l a_{C T X-M}$ and $b l a_{S H V}$ and none of isolates harbored all the three ESBL genes (Figures 2 and 3).
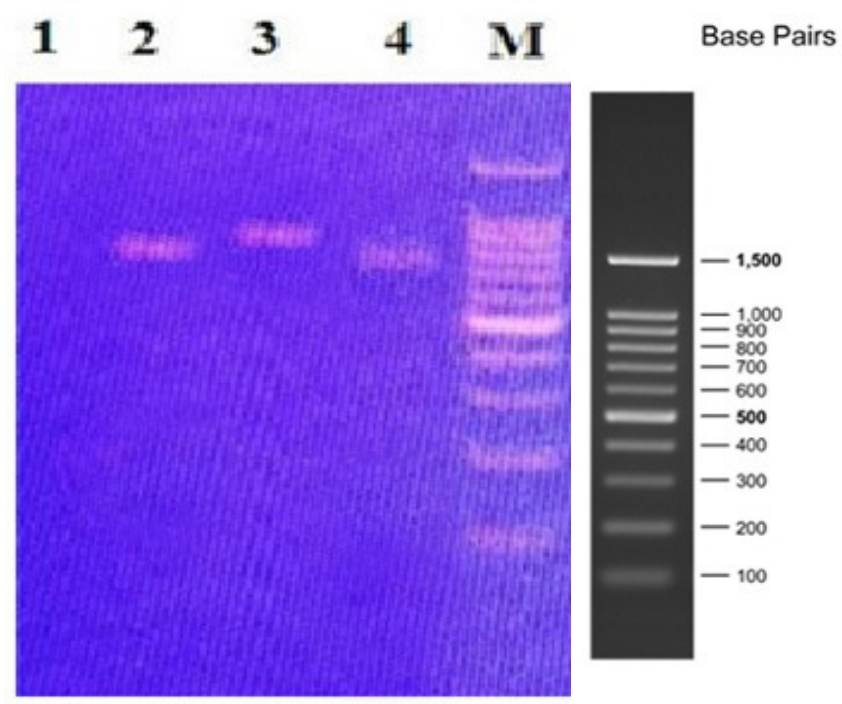

Figure 3. PCR amplification of Ambler class A ESBL genes. M: 100bp DNA ladder; 1: negative control; 2: bla $_{C T X-M}$ gene (909 bp) ; 3: bla $a_{T E M}$ gene (930 bp); 4: bla $a_{S H V}$ gene (868 bp).

\section{DISCUSSION}

The emergence of ESBL genes mediated drug resistance has been increased worldwide. Overuse of broad spectrum antibiotics such as the second, third and fourth generation cephalosporins and other $\beta$-lactams could be associated with increase of ESBL producing strains. Infections caused by such pathogens often limit therapeutic options and cause treatment failures (ROSSOLINI et al. 2007; ZAHAR et al. 2009). The effective control of infections and reduction of the occurrence of drug-resistant bacterial strains, it is imperative to investigate the current status of antibiotic resistance as well as the mechanisms which are involved in drug resistance.
High prevalence of ESBLs among enterobacteriaceae causing human infections in Iran has been reported by several researchers (FEIZABADI et al. 2010; RIYAHI ZANIANI et al. 2012). In our study, prevalence of ESBLs among UPEC isolates was investigated by CLSI phenotypic confirmatory assay and the ESBL genes were also genotyped using molecular assay. According to the phenotypic confirmatory test, only $52.8 \%$ of the isolates were identified as ESBL producers while molecular analysis detected at least one ESBL genes in $67.1 \%$ of the isolates. There are multiple mechanisms of resistance to $\beta$-lactam antibiotics in a single isolate (BUSH et al. 2011; DRIEUX et al. 2008). Co-existence of ESBLs with chromosomal cephalosporinases, plasmid mediated AmpCs and 
Prevalence of ambler class...

carbapenemases may complicate the phenotypic detection of ESBLs (POULOU et al. 2014; TZELEPI et al. 2008). Thus, the lower sensitivity of phenotypic assay could be attributed to the expression of other $\beta$-lactamases and repression of ESBL genes. The expression of the non ESBL $\beta$ lactamases can mask the presence of ESBLs, so that, in terms of phenotypic screening, the prevalences of ESBLs may be underestimated (GARREC et al. 2011; JEONG et al. 2008). Therefore, molecular detection of ESBL genes is a more accurate method compared to the phenotypic screening assay.

This study documented that there was significant difference in antibiotic resistance pattern between ESBL and non ESBL strains. ESBL producing strains displayed significantly higher resistance to ceftazidim (CAZ), ceftriaxone (CRO), cefazolin (CFZ), cefotaxime (CTX) as well as cefoxitin (FOX), while, there was no significant difference in resistance to other antibiotics. In addition, imipenem (IMP) was found as the most effective antibiotic against UPEC isolates. In addition, higher resistance rate to ciprofloxacin among ESBL producing UPEC isolates was observed in our study. ESBL genes are often cotransferred with plasmid-mediated fluoroquinolone and aminoglycoside resistance genes, which results in multidrug resistance of the isolates (CARATTOLI, 2009).

The types and frequencies of ESBL production by members of the Enterobacteriaceae have significantly changed recently. $b l a_{S H V}$ and $b l a_{T E M}$ derived ESBLs have arisen from mutations in
ZAMANI, H.; SALEHZADEH, A.; ZARRIN, S.

the very common genes that encode TEM-1 and SHV-1 enzymes (Jacoby and Munoz-Price 2005). In this study we reported the prevalence of $b a_{T E M}$ and $b l a_{S H V}$ genes to be 74.2 and $12.2 \%$ respectively. This finding was higher than the values reported by Riyahi Zaniani et al. (RIYAHI ZANIANI et al., 2012) who reported a prevalence of $b l a_{T E M}$ and $b l a_{S H V}$ ESBL genes in E. coli isolates around 13.4 and $0 \%$ respectively. The new group of ESBLs, the $b l a_{C T X-M}$ family, has rapidly emerged and become the predominant ESBL type in many parts of the world (PATERSON et al. 2003; PITOUT; LAUPLAND 2008). In our study we found $b a_{C T X-M}$ was the second dominant ESBL gene with the prevalence of $43.2 \%$. This was not in accordance with the results reported by Yazdi et al. (2012) and Nakhaei Moghaddam et al. (2012) who reported a significantly higher prevalence of $b l a_{C T X-M}$ among pathogenic E. coli strains. Thus, our study indicated that the prevalence of different ESBL genes varies in different geographic areas.

The high prevalence of ESBL genes among UPEC strains is a major challenge which needs more consideration. In addition, although phenotypic assay is an easy, time-saving and cost effective method, the molecular assay is more accurate and reliable. In our study, we determined prevalence of different ESBL genes among UPEC isolates as well as their antibiotic susceptibility profile. However, lack of molecular sub-typing of each ESBL genes is the limitation of our work which needs more investigation in future.

RESUMO: As $\beta$-lactamases de espectro alargado (ESBLs), um grupo de enzimas bacterianas que são a principal causa de resistência às penicilinas, cefalosporinas de largo espectro e monobactamas, encontram-se entre os membros das Enterobacteriaceae. As ESBLs de classe A são principalmente codificadas pelos genes $b l a_{S H V}$, $b l a_{T E M}$ e $b l a_{C T X-M}$ mediados por plasmídeo. Neste estudo, foi investigada a prevalência dos genes ESBL de classe A de Ambler entre isolados de E. coli uropatogênicos (UPEC) e seu padrão de suscetibilidade aos antibióticos. Setenta cepas UPEC foram isoladas a partir de amostras de urina e submetidas a ensaio de susceptibilidade antimicrobiana utilizando o método de difusão em disco. O rastreio fenotípico da produção de ESBL foi avaliado de acordo com o método de disco combinado CLSI. A genotipagem de ESBL de classe A de Ambler foi investigada usando PCR. De acordo com os resultados, as ESBLs foram identificadas em 37 isolados enquanto que o ensaio molecular mostrou 47 isolados portadores de genes ESBL. A maior prevalência foi registrada para $b l a_{T E M}(74,2 \%)$, seguida de $b l a_{C T X-M}(43,2 \%)$ e $b l a_{S H V}(12,2 \%)$. O imipenem foi o fármaco mais eficaz e os isolados produtores de ESBL apresentaram maior resistência a CAZ, CRO, CFZ, CTX e FOX em comparação com os isolados não ESBL. Em conclusão, a alta prevalência de genes ESBL de classe A foi observada em nosso estudo, que necessita de maior atenção e prescrição de antibióticos racionais.

PALAVRAS-CHAVE: Antibiograma. ESBL. Discos combinados fenotípicos. Uropathogenic E. coli. 


\section{REFERENCES}

BUSH, K.; FISHER, J. F. Epidemiological expansion, structural studies, and clinical challenges of new lactamases from Gram-negative bacteria. Annu. Rev. Microbiol., v. 65, p. 455-478, 2011.

https://doi.org/10.1146/annurev-micro-090110-102911

CANTON, R.; NOVAIS, A.; VALVERDE, A.; MACHADO, E.; PEIXE, L.; BAQUERO, F. Prevalence and spread of extended-spectrum blactamase- producing Enterobacteriaceae in Europe. Clin. Microbiol. Infect., v. 14, n. 1, p. 144-153, 2008. https://doi.org/10.1111/j.1469-0691.2007.01850.x

CARATTOLI, A. Resistance plasmid families in Enterobacteriaceae. Antimicrob. Agents Chemo., v. 53, p. 2227-2238, 2009. https://doi.org/10.1128/AAC.01707-08

CLSI . Susceptibility Testing; Twenty-Second Informational Supplement M100-S22, v. 32, n. 3, 2012.

DRIEUX, L.; BROSSIER, F.; SOUGAKOFF, W.; JARLIER, V. Phenotypic detection of extended spectrum $\beta$ lactamase production in Enterobacteriaceae: review and bench guide. Clin. Microbiol. Infect., v. 14, n. 1, p. 90-103, 2008. https://doi.org/10.1111/j.1469-0691.2007.01846.x

FEIZABADI, M. M.; MOHAMMADI-YEGANEH, S.; MIRSALEHIAN, A.; AZIMI, P.; MIRAFSHAR, S. M.; MAHBOOBI, M. Genetic characterization of ESBL-producing strains of Klebsiella pneumoniae from Tehran hospitals. J. Infect. Dev. Ctries., v. 4, p. 609-615, 2010. https://doi.org/10.3855/jidc.1059

GARREC, H.; DRIEUX-ROUZET, L.; GOLMARD, J. L.; JARLIER, V.; ROBERT, J. Comparison of nine phenotypic methods for detection of extendedspectrum $\beta$-lactamase production by Enterobacteriaceae. J. Clin. Microbiol., v. 49, p. 1048-1057, 2011. https://doi.org/10.1128/JCM.02130-10

GARZA-GONZALEZ, E.; IBARRA S. I.; LIACA-DIAZ J. M.; GONZALEZ G. M. Molecular characterization and antimicrobial susceptibility of extended-spectrum $\beta$-lactamase-producing Enterobacteriaceae isolates at a tertiary-care centre in Monterrey, Mexico. J. medic. Microbial., v. 60, n. 1, p. 84-90, 2011.

https://doi.org/10.1099/jmm.0.022970-0

JACOBY, G. A.; MUNOZ-PRICE, L. S. The new ß-lactamases. N. Engl. J. Med., v. 352, p. 380-391, 2005. https://doi.org/10.1056/NEJMra041359

JEONG, S. H.; SONG, W.; PARK, M. J.; KIM, J. S.; KIM, H. S., BAE, I. K. Boronic acid disk tests for identification of extended-spectrum $\beta$-lactamase production in clinical isolates of Enterobacteriaceae producing chromosomal AmpC $\beta$-lactamases. Int. J. Antimicrob. Agents., v. 31, p. 467-471, 2008.

https://doi.org/10.1016/j.ijantimicag.2007.12.014

JORGENSEN, J. H.; MCELMEEL, M. L.; FULCHER, L. C.; ZIMMER, B. L. Detection of CTX-M-Type extended-spectrum beta-lactamase (ESBLs) by testing with MicroScan overnight and ESBL confirmation panels. J. clinic. Microbial., v. 48, n. 1, p. 120-123, 2010. https://doi.org/10.1128/jcm.01507-09

KAUR, M.; AGGARWAL, A. Occurrence of the CTX-M, SHV and the TEM genes among the extended spectrum $\beta$-lactamase producing isolates of enterobacteriaceae in a Tertiary Care Hospital of North India. J. clinic. Diagnos. Res., v. 7, n. 4, p. 642, 2013. https://doi.org/10.7860/jcdr/2013/5081.2872

KIARASTIN, P.; APISARNTHANARAK, A.; LAESRIPA, C.; SAIFON P. Molecular characterization and epidemiology of extended-spectrum-lactamase producing Escherichia coli and Klebsiella pneumonia isolates causing health care-associated infection in Thailand, where the CTX-M family is endemic. Antimicrob.

Agents Chemo., v. 52, p. 2818-24, 2008. https://doi.org/10.1128/AAC.00171-08 
KIRATISIN, P.; APISARNTHANARAK, A.; SAIFON, P.; LAESIPA, C.; KITPHATI, R.; MUNDY, L. M. The emergence of a novel ceftazidime-resistant CTX-M extended-spectrum $\beta$-lactamase, CTX-M-55, in both community-onset and hospital-acquired infections in Thailand. Diagnos microbial. infec. Dis., v. 58, n. 3, p. 349-355, 2007. https://doi.org/10.1016/j.diagmicrobio.2007.02.005

NAKHAEI M.; FORGHANIFARD, M. M.; MOSHREFI S. Prevalence and Molecular Characterization of Plasmid-mediated Extended-Spectrum $\beta$-Lactamase Genes (blaTEM, blaCTX and blASHV) Among Urinary Escherichia coli Clinical Isolates in Mashhad, Iran. Iran J. Basic Med. Sci., v. 15, n. 3, p. 833-9, 2012.

PARK, Y. J.; LEE, S.; YU, J. K.; WOO, G. J.; LEE, K.; ARAKAWA, Y. Co-production of 16S rRNA methylases and extended-spectrum $\beta$-lactamases in AmpC-producing Enterobacter cloacae, Citrobacter freundii and Serratia marcescens in Korea. J. Antimicrob. Chemo., v. 58, n. 4, p. 907-908, 2006.

https://doi.org/10.1093/jac/dk1317

PARVEEN, R. M.; MANIVANNAN, S.; HARISH, B. N.; PARIJA, S. C. Study of CTX-M type of extended spectrum $\beta$-lactamase among nosocomial isolates of Escherichia coli and Klebsiella pneumoniae in South India. Ind. J. microbial. , v. 52, n. 1, p. 35-40, 2012.

PATERSON, D. L.; HUJER, K. M.; HUJER, A. M.; YEISER, B.; BONOMO, M. D.; RICE, L. B. Extendedspectrum $\beta$-lactamases in Klebsiella pneumoniae bloodstream isolates from seven countries: dominance and widespread prevalence of SHV-and CTX-M-type $\beta$-lactamases. Antimicrob. Agents Chemother., v. 47, n. 11, p. 3554-3560, 2003. https://doi.org/10.1128/AAC.47.11.3554-3560.2003

PITOUT, J. D.; LAUPLAND, K. B. Extended-spectrum $\beta$-lactamase producing Enterobacteriaceae: an emerging public health-concern. Lancet Infect. Dis., v. 8, p. 159-166, 2008. https://doi.org/10.1016/S14733099(08)70041-0

POULOU, A.; GRIVAKOU, E.; VRIONI, G.; KOUMAKI, V.; PITTARAS, T.; POURNARA, S. Modified CLSI extended-spectrum $\beta$-lactamase (ESBL) confirmatory test for phenotypic detection of ESBLs among Enterobacteriaceae producing various $\beta$-lactamases. J. clinic. Microbial., v. 52, n. 5, p. 1483-89, 2014. https://doi.org/10.1128/jcm.03361-13

ROSSOLINI, G. M.; MANTEGOLI, E.; DOCQUIER, J. D.; MUSMANNO, R. A.; CORATZA, G. Epidemiology of infections caused by multiresistant gramnegatives: ESBLs, MBLs, panresistant strains. New Microbiol., v. 30, p. 332-339, 2007.

SHACHERAGHI, F.; SHAKIBAIE, M. R.; NOVEIRI, H. Molecular Identification of ESBL Genes "blaGES-1, blaVEB-1, blaCTX-M blaOXA-1, blaOXA-4, blaOXA-10 and blaPER-1 in Pseudomonas aeruginosa Strains Isolated from Burn Patients by PCR, RFLP and Sequencing Techniques. I. J. of Biol. and L. Sc., v. 6, p. 3, 2010.

RIYAHI ZANIANI, F.; MESHKAT, Z.; NADERI NASAB, M.; KHAJE-KARAMADINI, M.; GHAZVINI, K.; REZAEE, A.; ESMAILY, H.; DARBAN HOSEINI, M. The prevalence of TEM and SHV genes among extended-spectrum beta-lactamases producing Escherichia coli and Klebsiella pneumoniae. Iran. J. of BASIC. Med. Sic. V. 15, n. 1, p. 654-60, 2012.

TZELEPI, E.; GIAKKOUPI, P.; SOFIANOU, D.; LOUKOVA, V.; KEMEROGLOU, A.; TSAKRIS, A. Detection of extended-spectrum _-lactamases in clinical isolates of Enterobacter cloacae and Enterobacter aerogenes. J. Clin. Microbiol., v. 38, p. 542-546, 2008.

YAZDI, M.; NAZEMI, A.; MIRINARGASI, M.; JAFARPOUR, M.; SHARIFI, S. H. Genotypic versus phenotypic methods to detect extended- spectrum $\beta$ - lactamases (ESBLs) in Uropathogenic Escherichia coli. Ann. Biol. Res., v. 3, n. 5, p. 2454- 58, 2012.

ZAHAR, J. R.; YORTHOLARY, O.; MARTHIN, C.; POTEL, G.; PLESIAT, P.; NORDMANN, P. Addressing the challenge of extended-spectrum $\beta$-lactamases. Curr. Opin. Investig. Drugs., v. 10, p. 172-180, 2009. 